ESP's career as a statistician touched many fields, ranging from pure research to applied methodology, from editing journals to the teaching of wide and disparate groups. To it all he brought a humility of approach and manner that was endearing to those who came into contact with him. His presidential address to the Royal Statistical Sociely in 1956 showed him at his best in demonstrating how common sense could be fruitfully applied to the analysis of data. Although my own personal interests in the applications of statistical methods diverged from his in later years, he was always ready to listen to a different viewpoint and a fresh approach. His loss is a grievous one, but he leaves behind him much that will be admired by the generations that follow.

P. G. MOORE

\title{
ROBERT OSWALD BLYTH
}

Robert Oswald Blyth, died on 9 September 1980, aged 97. He became a Fellow in 1913. He joined Scottish Amicable life Assurance Society in May 1905 having graduated as an M.A. at Glasgow University. His father Robert Blyth C.A., F.F.A. had been General Manager of that Office from 1891 to 1894 and then General Manager of the Union Bank of Scotland. Oswald Blyth qualified as a Fellow of the Faculty in 1909.

After war service on the HQ staff of the Heavy Artillery Training Centre at Winchester he returned to Scottish Amicable and after a spell in London was appointed Assistant Manager at Head Office, a position which he held until he decided to retire early on 31 December 1928.

In his retirement he pursued his love of ornithology and became a well-known authority on birds and their habits. He in fact kept a record every day for over 80 years of the species of bird he had seen that day. He remained in excellent health until close to the end of his long life and enjoyed a period of retirement of over 50 years. At the time of his death he was the oldest Fellow of both the Faculty and the Institute, having theen born on 18 May 1883. At the time of his death he was the senior Fellow of the Faculty by length of time qualified.

M. D. Paterson 